ISBN 978-93-84468-86-6

2016 International Research Conference on Social Sciences, Humanities and Interdisciplinary Studies

(RCSSHIS-2016)

Pattaya (Thailand) Dec. 16-17, 2016

\title{
Factors of Purchasing Decision Behavior of Men's Face Cleansing Foam in Minburi Region
}

\author{
Dr. Chinnaso Visitnitikija, and LingminLuo \\ chinnaso12@gmail.com \\ Post Graduate School of business administration \\ Kasembundituniversity,Bangkok
}

\begin{abstract}
The purpose of this study was to determine factors of purchasing decision behavior of men's face cleansing foam in Minburi region. The samples of this study were 400 customers who purchased men's cleansing foam from the store by using questionnaire as a tool and the statistical analysis data were percentage, mean, standard deviation, Chi square, and Regression analysis.

Findings indicated that most of respondents were 20-29 years old, single marital status, bachelor degree graduated, monthly average income 10,000-20,000 baht, used cleansing foam twice a day, selected from interesting advertising, and purchased NIVEA brand with 150 grams size imported cleansing foam from neighborhood store with average 7 times and value about 1,400 baht annually for face cleaning reason. The average picture of the opinions of marketing mix influence purchasing decision behavior of men's face cleansing foam were in the high level, such as foam quality, harmless to use, appropriate price to product quality, easy access to distributors channel, especially from big department store which carries assorted of foam products, knowledgeable sale persons, most of consumer emphasis on marketing mix of products, and sale promotion, respectively. In addition, the average picture of the opinion of products, distribution channel, sale promotion have relationship with factors of purchasing decision behavior of men's face cleansing foam in Minburi region. Recommendations from this study were that men's face cleansing foam distributors should be given priority in selecting the imported cleansing quality products, Safe skin care which washarmless to use, appropriate prices to quality of products, additional distribution channels, open 7 days a week, easy access location, trained personnel, and products advertising with all media channels.
\end{abstract}

Keywords: Factors, Decision, Behavior

\section{Introduction}

The current lifestyle of Thai people facing air pollution has been found to be present widely in the environment. A number of studies show that pollution has an adverse effect on the productivity of both indoor and outdoor workers. With increasing human population, pollution has become a great concern.Cosmetics, also known as make-up, are substances or products used to enhance the appearance or fragrance of the body. Many cosmetics are designed for use on the face and hair. In the 21 st century, women generally use more cosmetics than men. They are generally mixtures of chemical compounds; some being derived from natural sources (such as coconut oil), and some being synthetics. Common cosmetics include lipstick, mascara, eye shadow, foundation, rouge, skin cleansers and skin lotions, shampoo, hairstyling products (gel, hair spray, etc.), perfume, and cologne. In the U.S., the Food and Drug Administration (FDA), which regulates cosmetics, defines cosmetics as "intended to be applied to the human body for cleansing, beautifying, promoting attractiveness, or altering the appearance without affecting the body's structure or functions." This broad definition includes any material intended for use as a component of a cosmetic product. The FDA specifically excludes soap from this category help to heal skin damage caused by the sun and external toxins in the air, Leave their skin looking healthy, smooth and free of redness or irritation while helping keep those wrinkles at bay. Beauty products are now widely available from dedicated Internet-only retailers, who have more recently been joined online by 
established outlets, including the major department stores and traditional bricks and mortar beauty retailers. Although modern make-up has been traditionally used mainly by women, an increasing number of men are using cosmetics usually associated to women to enhance or cover their own facial features such as blemishes, dark circles, and so on. Concealer is commonly used by men. Cosmetics brands release products especially tailored for men, and men are increasingly using them.

As for information of Bangkok population surveys in year 2550 from Ministry of Interior (2553) indicated that male population age between 20-40 years old are approximately 913,650 persons (15.98 percent) of the whole population, it is consider quite a lot of numbers of males Thai population and because world surrounding atmosphere changed so that this in turn man behavior regarding of take care of themselves has changed as well.

As information mentioned above, research are interested in studying factors of purchasing decision behavior of men's face cleansing foam in Minburi region.

\section{Literature Review}

According to Philip Kotler - "Marketing Mix is the combination of four elements, called the 4P's (product, Price, Promotion, and Place), that every company has the option of adding, subtracting, or modifying in order to create a desired marketing strategy"

According to Principles of Marketing, 14e, Kotler and Armstrong, 2012 - "The Marketing Mix is the set of tactical marketing tools - Product, Price, Promotion, and Place - that the firm blends to produce the response it wants in the target market."

4P's - Producer-oriented Model of Marketing Mix

Product - Products are offerings that a marketer offers to the target audience to satisfy their needs and wants. Product can be tangible good or intangible service. Tangible products are goods like - cellphone, television, or motor car, whereas intangible products are services like - financial service in a bank, health treatment by a doctor, legal advice of a lawyer.

Price - Price is the amount that is charged by marketer of his offerings or the amount that is paid by consumer for the use or consumption of the product. Price is crucial in determining the organization's profit and survival. Adjustments in price affects the demand and sales of the product. Marketers are required to be aware of the customer perceived value of the product to set the right price.

Promotion - Promotion represents the different methods of communication that are used by marketer to inform target audience about the product. Promotion includes - advertising, personal selling, public relation, and sales promotion.

Place - Place or distribution refers to making the product available for customers at convenient and accessible places.

\section{Purpose of the Study}

1. To study the purchasing decision behavior of men's face cleansing foam in Minburi District

2. To study the marketing mix factor that affects the purchasing decision behavior of men's face cleansing foam in Minburi District.

Conceptual frameworks of the study
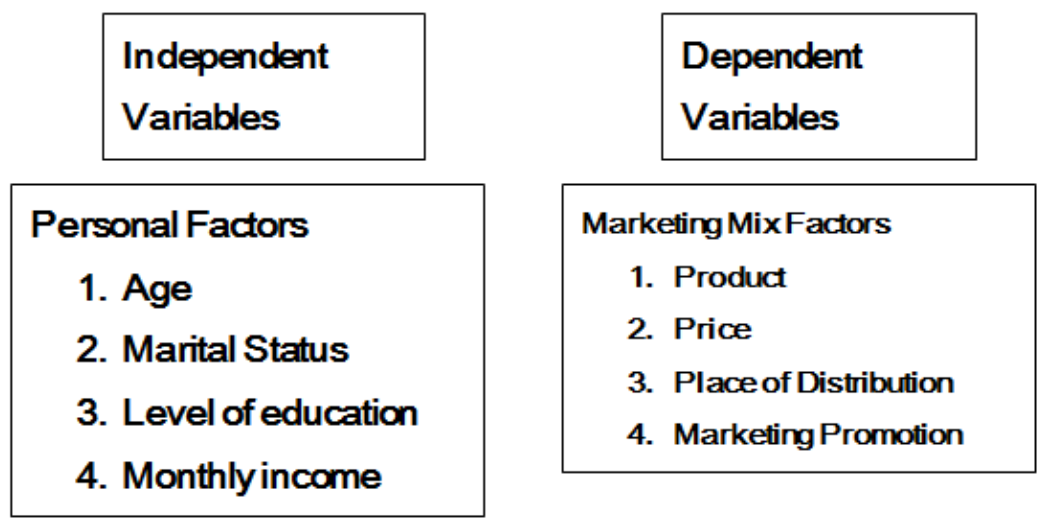


\section{Research Methodology}

\section{Sample selection}

Sample size for $\pm 5 \%, \pm 7 \%$ and $\pm 10 \%$ PrecisionLevels Where Confidence Level is $95 \%$ and $\mathrm{P}=.5$.

Assume there isa large population but that we do not know thevariability in the proportion that will adopt thepractice; therefore, assume $\mathrm{p}=.5$ (maximumvariability). Furthermore, suppose we desire a 95\%confidence level and $\pm 5 \%$ precision. The resultingsample size is demonstrated in Equation.

$$
n_{0}=\frac{Z^{2} p q}{e^{2}}=\frac{(1.96)^{2}(.5)(.5)}{(.05)^{2}}=385 \text { farmers }
$$

The samples were 400 peoplewho used men's cleansing foam.

\section{Data collection procedure}

The questionnaires were distributed to sample of 400 people who used men's cleansing foam. A total of 400 usable questionnaires were returned back to the researcher, yielding a 100 percent response rate and no missing data.

\section{Results}

TABLE I Comparison of the factors of personal difference, such as age, marital status, level of education, monthly income effect factors of purchasing decision behavior of men's face cleansing foam in Minburi Region.

\begin{tabular}{|l|c|c|}
\hline Purchase behavior of buying men's cleansing foam & Pearson-Chi Square & Sig. \\
\hline 1. How often of using foam per day & 100.516 & 0.000 \\
2. Who make purchasing decision & 45.320 & 0.000 \\
3. Reason for using cleansing foam & 30.123 & 0.003 \\
4. Place to buy cleansing foam & 16.919 & 0.010 \\
5. Which channel to use when buying foam & 13.621 & 0.034 \\
6. What factory preference & 15.71. & 0.015 \\
7. Which brand to select & 82.916 & 0.000 \\
8. What Cleansing foam size & 31.713 & 0.000 \\
9. Benefit of cleansing foam & 27.490 & 0.001 \\
10. Preference of Aroma & 32.158 & 0.000 \\
11. How often of buying cleansing foam & 102.233 & 0.000 \\
12. How much money to spend & 223.699 & 0.000 \\
\hline
\end{tabular}

From table 1: hypothesis testing revealed that the comparison of personal difference of age effect factors of purchasing decision behavior of men's face cleansing foam as detail, such as How often of using foam per day, who make purchasing decision, reason for using cleansing foam, place to buy cleansing foam, which channel to use when buying foam, what factory preference, which brand to select, cleansing foam size, benefit of cleansing foam, preference of Aroma, How often of buying cleansing foam, and how much money to spendwhich valued of probability (p) less than 0.05 that mean personal difference, such age effected factors of purchasing decision behavior of men's face cleansing foam.

TABLE II comparison of the factors of personal difference, such as marital status effect factors of purchasing decision behavior of men's face cleansing foam in Minburi Region.

\begin{tabular}{|c|c|c|}
\hline Purchase behavior of buying men's cleansing foam & Pearson-Chi Square & Sig. \\
\hline 1. How often of using foam per day & 19.149 & 0.014 \\
\hline 2. Who make purchasing decision & 34.952 & 0.000 \\
\hline 3. Reason for using cleansing foam & 21.646 & 0.006 \\
\hline 4. Place to buy cleansing foam & 95.144 & 0.000 \\
\hline 5. Which channel to use when buying foam & 12.706 & 0.013 \\
\hline 6. What factory preference & 31.487 & 0.000 \\
\hline 7. Which brand to select & 34.262 & 0.000 \\
\hline 8. What Cleansing foam size & 19.395 & 0.004 \\
\hline
\end{tabular}


From table 2: hypothesis testing revealed that the comparison of personal difference of marital status effect factors of purchasing decision behavior of men's face cleansing foam as detail, such as How often of using foam per day, who make purchasing decision, reason for using cleansing foam, place to buy cleansing foam, which channel to use when buying foam, what factory preference, which brand to select, cleansing foam size, benefit of cleansing foam, preference of Aroma, How often of buying cleansing foam, and how much money to spend which valued of probability (p) less than 0.05 that mean personal difference, such marital status effected factors of purchasing decision behavior of men's face cleansing foam.

TABLE III comparison of the factors of personal difference, such as level of education effect factors of purchasing decision behavior of men's face cleansing foam in Minburi Region.

\begin{tabular}{|l|c|c|}
\hline Purchase behavior of buying men's cleansing foam & Pearson-Chi Square & Sig. \\
\hline 1. How often of using foam per day & 26.830 & 0.001 \\
2. Who make purchasing decision & 29.275 & 0.000 \\
3. Reason for using cleansing foam & 41.590 & 0.000 \\
4. Place to buy cleansing foam & 28.434 & 0.000 \\
5. Which channel to use when buying foam & 34.303 & 0.000 \\
6. What factory preference & 20.231 & 0.000 \\
7. Which brand to select & 40.075 & 0.000 \\
8. What Cleansing foam size & 15.555 & 0.016 \\
9. Benefit of cleansing foam & 26.066 & 0.000 \\
10. Preference of Aroma & 73.068 & 0.000 \\
11. How often of buying cleansing foam & 74.350 & 0.000 \\
12. How much money to spend & 157.828 & 0.000 \\
\hline
\end{tabular}

From table 3: hypothesis testing revealed that the comparison of personal difference, such as level of education effect factors of purchasing decision behavior of men's face cleansing foam as detail, such as How often of using foam per day, who make purchasing decision, reason for using cleansing foam, place to buy cleansing foam, which channel to use when buying foam, what factory preference, which brand to select, cleansing foam size, benefit of cleansing foam, preference of Aroma , How often of buying cleansing foam, and how much money to spend which valued of probability (p) less than 0.05 that mean personal difference, such level of education effected factors of purchasing decision behavior of men's face cleansing foam.

TABLE IV comparison of the factors of personal difference, such as monthlyincome effect factors of purchasing decision behavior of men's face cleansing foam in Minburi Region.

\begin{tabular}{|l|c|c|}
\hline Purchase behavior of buying men's cleansing foam & Pearson-Chi Square & Sig. \\
\hline 1. How often of using foam per day & 100.824 & 0.000 \\
2. Who make purchasing decision & 46.194 & 0.001 \\
3. Reason for using cleansing foam & 48.432 & 0.000 \\
4. Place to buy cleansing foam & 33.343 & 0.000 \\
5. Which channel to use when buying foam & 91.789 & 0.000 \\
6. What factory preference & 31.830 & 0.000 \\
7. Which brand to select & 125.325 & 0.000 \\
8. What Cleansing foam size & 46.564 & 0.000 \\
9. Benefit of cleansing foam & 76.508 & 0.000 \\
10. Preference of Aroma & 44.092 & 0.000 \\
\hline
\end{tabular}

From table 4: hypothesis testing revealed that the comparison of personal difference, such as monthly income effect factors of purchasing decision behavior of men's face cleansing foam as detail, such as How often of using foam per day, who make purchasing decision, reason for using cleansing foam, place to buy cleansing foam, which channel to use when buying foam, what factory preference, which brand to select, cleansing foam size, benefit of cleansing foam, preference of Aroma, How often of buying cleansing foam, and how much money to spend which valued of probability (p) less than 0.05 that mean personal difference, such asmonthly income effected factors of purchasing decision behavior of men's face cleansing foam. 


\section{Summary of Study Results}

Findings indicated that most of respondents were 20-29 years old, single marital status, bachelor degree graduated, monthly average income 10,000-20,000 baht, used cleansing foam twice a day, selected from interesting advertising, purchased NIVEA brand cleansing foam with 150 grams size, without fragrancewhich imported product from neighborhood store with average 7 times and value about 1,400 baht annually for face cleaning reason.

Summary of aspects of marketing mix factors affecting factors of purchasing decision behavior of men's face cleansing foam in Minburi Region.

Marketing mix aspect: the average picture of the opinion regardingfactors affecting factors of purchasing decision behavior of men's face cleansing foam were in high level, such as distribution channel, price, products, and marketing promotion.

Products aspect: the average picture of the opinion regarding factors affecting factors of purchasing decision behavior of men's face cleansing foam were in high level, such as foam quality, and harmless to use.

Prices aspect: the average picture of the opinion regarding factors affecting factors of purchasing decision behavior of men's face cleansing foam were in high level, such as appropriate price according to quality of product and label price accurately.

Distribution channel: the average picture of the opinion regarding factors affecting factors of purchasing decision behavior of men's face cleansing foam were in high level, such as open for business every day, good location with easy access, sale products in major department store, products assortment, and advertising thru internet.

Marketing promotion aspect: the average picture of the opinion regarding factors affecting factors of purchasing decision behavior of men's face cleansing foam were in high level, such as advertising with all media channels, free gift with purchase, seasonal discount prices, promotion event, and give away products sample, etc.

\section{Suggestions from the Study}

Recommendations from this study were that men's face cleansing foam distributors should be given priority in selecting the imported cleansing quality products, Safe skin care which was harmless to use, appropriate prices to quality of products, additional distribution channels, open 7 days a week, easy access location, trained personnel, and products advertising with all media channels.

\section{References}

[1] NontThitilertdacha. (2554). Opinion of Metrosexual men group, such as age between 20-40 yearOld, regarding of men cosmetics in Bangkok area. Cosmetics science department, Mae FahLuang University, publisher.

[2] ChacristVuttisukhum. (2554). Factors influencing decision on selecting private dormitory for Humanity department students of Chiang Mai University, term paper report, Agriculture department, Chiang Mai University, publisher.

[3] SaeriVongmonta. (2542). Analysis of consumer behavior, Chai Thera Film Co., Ltd., Bangkok

[4] SaeriVongmonta. (2542). Marketing Mix. [online]http://spssthesis.blogspot.com/.

[5] AdulJaturongkul. (2543). Variables of Marketing mix. )[online]http://spssthesis.blogspot.com/.

[6] ButsayaVetchalanont. (2554). Factors of Selection behavior in selecting high definitionCosmetics of undergrad students in Bangkok, Cosmetics science department, Mae FahLuang University, publisher,

[7] PrathanKaokeaw. (2553). Factors of men studentsselection behavior of buying cleansing foamin Bangkok and marketing mix assessment of the products. Independent Study, Master of Business Administration. Bangkok University.

[8] Günther Schneider, Sven Gohla, Jörg Schreiber, et al. "Skin Cosmetics" in Ullmann's Encyclopedia of Industrial Chemistry 2005, Wiley-VCH, Weinheim. doi:10.1002/14356007.a24_219

[9] "Cosmetics and Your Health - FAQs". Womenshealth.gov. November 2004.

[10] "Lessons from categorising the entire beauty products sector (Part 1)". p. 1. Retrieved 2009-09-28

[11] "FDA Authority OverCosmetics". Cfsan.fda.gov. Retrieved 2011-10-23. 